to Colonel Ernest Herbays, secretary-general of URSI, in recognition of his continuous and devoted service to the Union since 1928. In the volume now published recording these proceedings, Colonel Herbays very appropriately provided a concluding section outlining the history of the Union since the first meeting in 1912 of a few scientists interested in the investigation of the phenomena associated with 'electric waves'.

The production of this little volume is excellent in every way; and it forms a worthy memorial to the achievements of URSI and the part played in them by the late Dr. B. van der Pol. R. L. Smith-Rose

\title{
CANADIAN SOCIETY OF PLANT PHYSIOLOGISTS
}

$\mathrm{T}$ HE 1964 annual moeting of the Canadian Society of Plant Physiologists-la Société Canadienne de Physiologie Végétale - was recently held in Kingston, Ontario. The host institute was Queen's University.

The proceedings opened, on Juno 4, with a symposium on respiration under the chairmanship of Prof. Dorothy $\mathbf{F}$. Forward (University of Toronto). Dr. D. F. Parsons (Departmont of Modical Biophysics, University of Toronto) discussed his recent investigations of the structure and junction of mitochondrial membranes, using a negative staining technique for electron microscopy. Two types of projecting sub-units were found, one on the outer membrano, consisting of $60 \AA$ hollow cylinders, and the other on the cristæ, consisting of $90 \AA$ mushroom-shaped structures. The latter structures have been found in a wide variety of plant and animal tissues. These subunits are protein, but do not contain cytochromes. There is evidence for the presence of a flavoprotoin and an ATPase. The sub-units may be associated with oxidative phosphorylation.

Dr. W. D. Bonner, jun. (Johnson Rosoarch Foundation, University of Pennsylvania), prosented a paper on electron transport in plant mitochondria. He discussed the large number of cytochromes which have been described, and the difficulties in their characterization. Two $c$-type, three $b$-type and three $a$-type cytochromes are present in the mitochondria of all plant species, regardless of the respiratory characteristics. At normal concentrations of oxygon, when ADP is limiting (state-4 conditions), oxidation by plant mitochondria is not inhibited by hydrocyanic acid (HCN) or carbon monoxide (CO). However, when ADP is in excess (state-3 conditions), $\mathrm{HCN}+\mathrm{CO}$ reduces the rate to that of state-4. State-4 rate corresponds to the 'ground respiration' of plant physiological literature. This is completely inhibited at low concentrations of oxygen by $\mathrm{HCN}$ and $\mathrm{CO}$; the same is true in mitochondria which show HCN and CO insonsitive respiration (skunk cabbage). Kinetic analysis suggests that oxygen reacts with two separate oxidases. This is supported by optical demonstration of two $\mathrm{CO}\left(\mathrm{O}_{2}\right)$ binding pigments. The presence of a second $\mathrm{CO}$-binding pigment provides an explanation for both 'ground respiration' and 'cyanide insensitive respiration'.

The symposium was completed by a paper by Prof. G. Krotkov (Biology Department, Queen's University) on the effect of light on respiration, thus continuing the development of the symposium subject from the subcellular structural level to that of the physiology of the whole organism. The question of whether respiration is affected by light has in the past been answered by indirect means. The techniques used in Dr. Krotkov's laboratory made it possible to show that light and dark respiration are two different processes. 'Photorespiration', or evolution of carbon dioxido in light, involvos different pathways of metabolism, perhaps utilizing glycollic acid metabolism. Corn, a plant of exceptionally high productive ability, has no photorespiration, and appears to lack co-factors for glycollic acid oxidation. Corn does not 'waste' products of photosynthesis in respiration while it is illuminated, and is thus more efficient than other plants.

Six half-day sessions (two sossions always running concurrently) were devoted to contributed papors. A closely knit group of papers on translocation originated from the laboratories of the Division of Biosciences,
National Research Council, Ottawa, under the direction of Dr. P. R. Gorham and Dr. D. C. Mortimer, and from the laboratory of Dr. G. Krotkov and Dr. C. D. Nelson at Queen's University, the host institute. Dr. Mortimer's results showed that downward translocation of photosynthate occurred at greatly varying rates and intensities in difforont vascular bundles of a leaf, which thus had to be analysed separately. The Queen's University group showed that translocation of photosynthate is under hormonal control, and that there is seloctivo and preferential translocation of certain sugars.

The session on nitrogen included two papers from the laboratory of Dr. W. G. Boll (McGill University, Montreal) on the ability of ethanolamine to replace vitamin $\mathbf{B}_{6}$ in the nutrition of excised tomato roots, and on the biochemical mechanisms associated with this ability. An interesting paper from the laboratory of Dr. C. L. Mer (Imperial Colloge of Science and Technology, London (now visiting at Harvard University)) provided a nutritive hypothesis for growth responses in oat seedlings which precludes the necessity to postulate changes in auxin metabolism to account for various growth responses to changed environment.

A session on regulators was of general interest, and included papers on light quality and periodicity, on the regulation of enzyme synthesis, photosynthesis and nuclear activity by hormones and on the mode of action of herbicides.

Two sessions were held on metabolism, covering a wide range of research interests. A growing interest in the phenolic substances in plants was evidenced by a group of papers from the Halifax, Nova Scotia, laboratories of the National Research Council under the direction of Dr. A. C. Neish and Dr. G. H. N. Towers. These included very interesting work on the pathways of lignin biosynthe. sis and the interrelations of soluble and insoluble derivatives of the many $C_{6}-C_{1}$ and $C_{6}-C_{3}$ phenolic acids found in plants. Other papers included biosynthetic investigations on indoles, carbohydrates, phosphatides, alkaloids and chlorophylls. A number of papers were presented on various problems in plant metabolism, including organic acid metabolism, respiration, frost hardiness, and the influence of seasonal or environmental factors on plant metabolism.

A session was held on cell biology, which included cytological and cyto-physiological investigations on tissue cultures of Jerusalem artichoke and oat coleoptiles, originating from the Carleton University, Ottawa, laboratories of Dr. G. Setterfield and Dr. F. Wightman. It was shown that a number of synthetic auxins which promote cell expansion also promote cell division. Papers were presented on control mechanisms of amino-acid synthesis, on chloroplast bleaching in Euglena, and on histochemical tests. Dr. Nelson's group from Quoen's University presented work on the effect of auxin in controlling cellular pormeability, and on the electro-osmotic transport of sugars labelled with carbon-14 in Nitella cells.

The non-scientific event of outstanding significance at the meetings was the holding of a banquet in honour of Prof. D. L. Bailey (Botany Department, University of Toronto). Dr. Bailey is retiring from the editorship of the Canadian Journal of Botany, the official journal of the Society, after a number of years of outstanding service in which he has maintained the Journal at the highest possible standard. Special guests at the banquet included 
Dr. Leo Marion, oditor-in-chief of the Canadian Research Journals, and Dr. Pauline Snuro, manager of the editorial office.

At the business meeting it was decided that noxt yoar's annual meoting will be hold in early June at the University of New Brunswick, Fredericton, New Brunswick. Dr. G. Setterfield (Carleton University, Ottawa) was elocted president of the Society, Dr. A. R. A. Taylor (University of
New Brunswick) was elected vice-president, and Dr. R. G. S. Bidwell (University of Toronto) was re-elected secretary-treasurer. Other officers of the Society are Dr. M. Shaw (University of Saskatchewan) (past president), Dr. M. Cailloux (Úniversité de Montréal) (eastern director) and Dr. Mary Spencer (University of Alberta) (western director).

\author{
R. G. S. BIDWELL
}

\section{UNIVERSITY LIBRARY SERVICES}

A MEMORANDUM outlining the responsibilities and functions of university libraries has been submitted by the librarians of Britain's new universities to the Committee on Libraries of the University Grants Committee. It sets forth, first, the function of the university library; next, the level and scope of acquisitions; the need for undergraduate provision; and then discusses problems of building and accommodation and of library co-operation.

The memorandum begins by insisting that the first function of a university library is to support the teaching and research of the institution it serves, but that it also has a duty to the community of learning at large and access to its resources should be available to all serious students who need to consult them. As research grows and $\mathrm{a}$ larger proportion of the population receives a higher education, such extra-mural activities are likely to grow in importance, The memorandum insists that librarians must play a much moro positive part in exploiting the books in their libraries, both by information work and by giving instruction and guidance to students and research workers. Dealing with the lovel and scope of acquisitions, it indicates the magnitude and urgency of the situation confronting the new university librarians, and the acquisition of books and periodicals is seen as still the most important task which the university library must perform.

The library provision varies widely among the existing universities in Britain, and the inequality has increased rather than diminished since 1945. Only Cambridge, Oxford and London provide really comprehensive collections for research in Britain, although in the United States soveral university libraries have doubled or more than doubled their size since 1945. The rise in income of British university libraries during the past 15 years has been almost totally absorbed by the increase in publishing and the steady rise in prices. The memorandum suggests that the new universities should aim at collecting 250,000 volumes apiece during their first ten years, excluding multiple copies of undergraduate texts. Substantial capital grants will be required. The minimum cost of provision of periodicals in mathematical, physical, chemical and biological sciences may approach some $£ 10,000$ a year, although two-thirds of Britain's present universities spend less than this figure on periodicals and one-third spend less than $£ 5,000$.

The need for the student to have the use of a comprehensive library is emphasized by the memorandum, and it is pointed out that multiple provision of text-books makes possible a better lending service while provision of a reference copy ensures that both students and other users of the library can usually obtain access to certain books. The setting-up of separate undergraduate libraries in new universities is not favoured, but it is suggested that duplication of minimum book needs for each undergraduate course should be on a scale depending on the number of students involved. Funds available to university libraries, at least outside Oxford and Cambridge, are quite inadequate to provide multiple copies on the scale necessary, and students in some subjects cannot reasonably be expected to provide themselves with more than a small number of the many books they will need to consult in the course of three years. Grants are therefore needed for multiple book provision.

On buildings and accommodation, the memorandum points out that the new universities are in a position to take immediate advantage of the developments in university planning, particularly in the United States, since the Second World War and of recent developments in fast building techniques. University teaching methods will influence planning and the typical new library is likely to be designed on a flexible plan, with large open floors in which readers are placed close to blocks of bookshelves grouped according to subject. More generous space allowances are required and variety of provision for readers is essential. Some experiments in extended hours of opening are already being made. On co-operative storage and technical developments, the memorandum affirms the intention of the new universities to build up their libraries on the principle that the university library must possess within its own walls copies of almost everything required by its members for the promotion of their studies and the advancement of learning. However, it is believed that a proper policy for the withdrawal of obsolescent material should also be admitted. A national co-operative scheme now ensures that a copy of every recent worth-while British book is available for loan somewhere, but the universities still need to buy their own copies to cover their own requirements, and the possible advantages of a co-operative approach are regarded as worthy of investigation. Some advantage might accrue in the acquisition of periodicals from the co-operative coverage of all new titles of academic interest. The reductions available when a number of libraries purchase specially reproduced copies of out-of-print books are large enough to justify an attempt to set up a co-operative non-profit-making organization scheme. Any scheme for co-operative storage must provide for bibliographical care and maintenance so that material is available quickly when needed. The most immediate help in co-operative work that could be given is the provision of more funds for the important comprehensive catalogues, in particular, the national catalogues in the National Central Library. It is submitted in the memorandum that there is a strong case for amending the copyright regulations in the interests of efficiency and economy in learned institutions so as to facilitate the reproduction of copies from telefacsimiles and the request of photocopies by 'Telex'. There are difficulties in acquisition and in the use of microforms which militate against any substantial savings for libraries. However, the amount of bulky and little-used material kept in microform is likely to increase and to offer some economy in storage costs. More information is needed on many aspects of library organization, and none of the existing organizations is capable of undertaking this work. The memorandum suggests that there is scope for a small library development agency, the staff of which might both collect information and assist the co-oporation of academic libraries.

Copies of the memorandum can be obtained from $\mathrm{Mr}$. P. E. Tucker, librarian, the University of Warwick, Coventry, Warwicks. 